\title{
Influence of chronic pain on functional capacity of the elderly*
}

\author{
Influência da dor crônica na capacidade funcional do idoso
}

\author{
Bárbara Kayser ${ }^{1}$, Cascieli Miotto², Vinicius Dal Molin ${ }^{3}$ Julia Kummer ${ }^{4}$, Suelén Roberta Klein ${ }^{4}$, Lia Mara Wibelinger ${ }^{5}$
}

${ }^{*}$ Received from the Course of Physiotherapy, University of Passo Fundo, Passo Fundo, RS, Brazil.

\section{ABSTRACT}

BACKGROUND AND OBJECTIVES: Among locomotor system diseases, pain is the most frequent symptom and, in addition to its high prevalence, it is important because it is present in diseases causing the highest negative impact on quality of life and productivity of affected individuals. This study aimed at investigating relevant topics on the influence of chronic osteoarticular pain on the functional capacity of the elderly.

CONTENTS: A bibliographic study was carried out by querying major publications on the subject. Material was identified with the aid of electronic databases Medline, LILACS, Scielo and Pubmed. Keywords used were "chronic pain", "osteoarticular diseases" and "functional capacity".

CONCLUSION: Further attention should be given to public policies implementing programs aiming especially at preventing and controlling chronic osteoarticular diseases, promoting functionality and better quality of life for this population.

Keywords: Chronic pain, Functional capacity, Osteoarticular diseases.

\section{RESUMO}

JUSTIFICATIVA E OBJETIVOS: No âmbito das afecçôes do aparelho locomotor, a dor é o sintoma mais frequente e, além da alta prevalência, sua importância decorre por estar presente nas doenças que causam maior impacto negativo na qualidade de vida e na produtividade dos indivíduos acometidos. $\mathrm{O}$ objetivo deste estudo foi investigar tópicos relevantes sobre a influência da dor osteoarticular crônica na capacidade funcional no idoso.

1. University of Passo Fundo, Holder of Scholarship Pibic CNPq, Passo Fundo, RS, Brazil. 2. University of Passo Fundo, Holder of Scholarship Pibic/University of Passo Fundo, Passo Fundo, RS, Brazil.

3. University of Passo Fundo, Holder of Scholarship Probic Fapergs, Passo Fundo, RS, Brazil. 4. University of Passo Fundo, Passo Fundo, RS, Brazil.

5. University of Passo Fundo, Catholic University of Rio Grande do Sul, Passo Fundo, RS, Brazil.

Submitted in May 03, 2013.

Accepted for publication in November 26, 2013.

Conflict of interests: none.

\section{Correspondence to:}

Cascieli Miotto

Rua Doutor Bozano, 580/Bloco F/103 - Bairro Petrópolis.

99051-370 Passo Fundo, RS, Brazil.

E-mail: cascielimiotto@hotmail.com

(c) Sociedade Brasileira para o Estudo da Dor
CONTEÚDO: Foi realizado um estudo bibliográfico mediante consulta às principais publicaçóes sobre o tema. $\mathrm{O}$ material foi identificado com auxílio das bases eletrônicas de dados da Medline, LILACS, Scielo e Pubmed. Foram empregados os descritores "dor crônica", "doenças osteoarticulares" e "capacidade funcional".

CONCLUSÃO: Deve haver maior atenção às políticas públicas de implementação de programas que visem principalmente a prevenção e o controle das doenças crônicas osteoarticulares, promovendo funcionalidade e maior qualidade de vida para essa população.

Descritores: Capacidade funcional, Doenças osteoarticulares, Dor crônica.

\section{INTRODUCTION}

Aging is in general characterized by a high incidence of chronic and degenerative diseases which often result in high dependence. Many of such presentations are followed by pain and in a significant number of patients chronic pain is the major complaint and may markedly affect the quality of life of the elderly ${ }^{1-3}$.

Among locomotor system diseases, pain is the most frequent symptom and a major reason for looking for medical care. In addition to its high prevalence, pain may be present in diseases causing the highest negative impact on affected individuals' productivity ${ }^{4}$.

In most disabling diseases, pain is a consequent condition, varying in intensity and according to the evolution of the disease. Investigators have observed and emphasized that the high prevalence of pain among the elderly is normally associated to chronic disorders, among them arthritis and osteoporosis, and is influenced by high levels of functional incapacity and fragility ${ }^{5-7}$.

To determine the prevalence of chronic pain in the elderly and characterize it as to site, intensity, duration, frequency and specific time of day, a population of 451 elderly was studied and it was observed that the prevalence of chronic pain was $51.44 \%$. Most common painful sites were: dorsal region $(21.73 \%)$ and lower limbs (21.5\%). Dorsal pain was described as daily $(31.63 \%)$, continuous or lasting from 1 to 6 hours $(19.39 \%)$, mild (50\%) and without specific time of day (56.12\%). Pain in lower limbs was described as daily (42.27\%), with variable duration $(32.99 \%)$ or continuous $(22.68 \%)$, mild $(53.61 \%)$ and without specific time of day $(48.45 \%)^{8}$.

The National Elderly Health Policy assumes that the primary problem affecting the elderly as a consequence of the evolution of their diseases and lifestyle is the loss of functional capac- 
ity, that is, the loss of physical and mental skills necessary to perform basic and instrumental daily life activities?. The older population is the one progressing the most with regard to functional incapacity, which demands further care, thus higher costs to society ${ }^{10}$.

Rheumatoid arthritis, osteoarthritis, polymyalgia and osteoporosis are diseases which more frequently cause chronic musculoskeletal pain and incapacity in Brazil and worldwide ${ }^{11}$.

A theoretical study was carried out by searching major publications on the subject. The material was identified with the aid of Medline, LILACS, Scielo and Pubmed electronic databases. Keywords were "chronic pain", "osteoarticular diseases" and "functional capacity".

This study aimed at investigating relevant topics about the influence of chronic osteoarticular pain on the functional capacity of the elderly.

\section{OSTEOARTHRITIS}

Osteoarthritis $(\mathrm{OA})$ is a degenerative joint disease being the most prevalent rheumatic disease among individuals above 65 years of age. The World Health Organization (WHO) estimates that $25 \%$ of individuals above 65 years of age have OA-induced pain and incapacity ${ }^{12}$.

This is a painful disease caused by joint cartilage insufficiency, triggered by imbalance between formation and destruction of its primary elements. It is also associated to several conditions, such as: mechanical overload, cartilage and synovial membrane biochemical changes and genetic factors ${ }^{13}$.

Among clinical presentations, hip and knee OA are especially important for being particularly more disabling since these are joints supporting the whole body weight ${ }^{14}$. From knee and hip OA patients, approximately $80 \%$ report muscle function problems, specifically with regard to strength, resistance, balance and coordination ${ }^{15}$.

Clinical approaches used for osteoporosis pain relief are made up of: fast acting symptomatic drugs, narcotic and non-narcotic analgesics, non-steroid and steroid anti-inflammatory and intraarticular hyaluronic acid. Among non-pharmacological interventions there are: education of patients and relatives and adjuvant therapies ${ }^{16}$.

A study has evaluated the effect of sensory level transcutaneous electric nerve stimulation (TENS) to manage pain in patients with knee OA. The study involved 10 patients using TENS, with parameters of $80 \mathrm{~Hz}$ and $140 \mu \mathrm{s}$, in a total of 10 sessions lasting 30 minutes each. Total treatment period was 4 weeks. Each patient was interviewed with a pain evaluation questionnaire in the $1^{\text {st }}, 5^{\text {th }}$ and $10^{\text {th }}$ session. At the end of the study, authors have observed that TENS was satisfactory to decrease pain and improve knee functionality ${ }^{17}$.

\section{RHEUMATOID ARTHRITIS}

Rheumatoid arthritis (RA) is an inflammatory joint disease of chronic evolution, characterized by painful events and physical deformities, with consequent limitations for work and daily ac- tivities ${ }^{18}$. The disease evolves with different levels of functional incapacity and is associated to increased morbidity and mortality rates as compared to normal population ${ }^{19}$.

In joints, patients have physical capacity limitation due to decreased muscle strength, aerobic capacity and muscle resistance, due to pain, edema, decreased proprioception and loss of joint stability. Among extra-joint manifestations, one may mention fever, asthenia, fatigue, skin and vascular changes, lymphadenopathy, splenomegaly, eye, heart and lungs manifestations, rheumatic neuropathy, anemia and the presence of subcutaneous rheumatoid nodules ${ }^{20}$.

In a retrospective analysis of demographic and clinical characteristics of RA patients in ambulatory follow up in the state of São Paulo, 1,381 clinical records of patients seen between the years 2002 and 2005 were reviewed. With regard to pain, the research has observed that $67 \%$ of patients had pain complaint in the last recorded visit and pain was present regardless of the time when the disease was diagnosed. Still, only $15 \%$ of patients were not under painkillers ${ }^{21}$.

In an interventionist study using hydrotherapy in patients with RA, 8 volunteers were submitted to 10 sessions of 45 minutes, twice a week. Patients were evaluated pre and post-intervention and the conclusion was that hydrotherapy was beneficial for the quality of life and pain of treated patients ${ }^{22}$.

\section{POLYMYALGIA RHEUMATICA}

Polymyalgia rheumatica $(\mathrm{PR})$ is a rheumatologic disease in general affecting the elderly, with incidence in Mediterranean countries of 12.7/100,000 people aged 50 years or above. The etiology of the disease is still unknown, although environmental and genetic factors may be in its origin and it is more frequent among females $(2: 1)^{23}$.

It is characterized as a disease with risk of incapacity, especially if there is risk of blindness; however its treatment is effective and available in primary health care centers ${ }^{24}$.

A descriptive transversal study has evaluated the influence of chronic pain in the quality of life of the elderly. The WHOQOL questionnaire was used to evaluate quality of life and the visual analog scale (VAS) was used to evaluate pain. The study has shown the presence of moderate pain negatively influencing the quality of life of the elderly ${ }^{25}$.

Hydrotherapy seems to be highly indicated for such patients since it is related to improved quality of life. A study has shown that hydrotherapy is effective to treat fibromyalgia and is significantly better as compared to ground activities, leading to pain decrease ${ }^{26}$.

\section{OSTEOPOROSIS}

Osteoporosis is a systemic skeletal disease characterized by decreased bone mass and microarchitectural deterioration of bone tissue, with consequent increase in brittleness and susceptibility to fractures ${ }^{27}$.

In Brazil there are few data on the population affected by osteoporosis $^{28}$. According to the International Osteoporosis Founda- 
tion $^{29}$, it is estimated that approximately 10 million Brazilians suffer with osteoporosis, being that 2.4 million have annual fractures and from them approximately 200 thousand will die as a direct consequence of fractures.

Skeletal changes decrease chest and abdominal cavities capacity, with consequent change in cardiac, pulmonary, gastric and vesical function. Hip and distal forearm fractures in general occur after a fall. Approximately $30 \%$ of individuals above 65 years of age fall once a year or more and, from them, 3\% develop fractures ${ }^{30}$.

Pain is not caused by osteoporosis; it is manifested by low back pain related to vertebral micro-fractures by compression or by collapse or wedging of the vertebral body, sometimes with major spinal pain; and by partial or complete vertebral fractures leading to deterioration of quality of life ${ }^{31}$.

Osteoporosis patients when submitted to physical activity programs improve their pain sensation and significantly decrease the use of analgesics, with consequent improvement in mobility and functional capacity, in addition to bone mass gain ${ }^{32}$.

\section{CONCLUSION}

Chronic pain affects approximately 100 million individuals worldwide and is related to joints and to the musculoskeletal system. This understanding is important for the planning of public policies and for the implementation of programs aiming especially at prevention and control of chronic osteoarticular diseases, promoting further functionality and quality of life for such population.

\section{REFERENCES}

1. Silva MC, Fassa AG, Valle NC. [Chronic low back pain in a Southern Brazilian adult population: prevalence and associated factors]. Cad Saude Publica. 2004;20(2):37785. Portuguese.

2. Brennan DS, Singh KA. Dietary, self-reported oral health and socio-demographic predictors of general health status among older adults. J Nutr Health Aging. 2012;16(5):437-41

3. de Carvalho JA, Garcia RA. [The aging process in the Brazilian population: a demographic approach]. Cad Saude Publica. 2003;19(3):725-33. Portuguese.

4. Roux CH, Guillemin F, Boini S, Longuetaud F, Arnault N, Hercberg S, et al. Impact of musculoskeletal disorders on quality of life: an inception cohort study. Ann Rheum Dis. 2005;64(4):606-11.

5. Andrade FA, Pereira LV, Sousa FA. [Pain measurement in the elderly: a review]. Rev Lat Am Enfermagem. 2006;14(2):271-6. Portuguese.

6. Almeida HO, Versiani ER, Dias AR, Novaes MR, Trindade EM. Adesão a tratamentos entre idosos. Com Ciências Saúde. 2007;18(1):57-67.

7. Duarte YA, de Andrade CL, Lebrão ML. [Katz Index on elderly functionality evalua- tion]. Rev Esc Enferm USP. 2007;41(2):317-25. Portuguese.

8. Dellaroza MS, Pimenta CA, Matsuo T. [Prevalence and characterization of chronic pain among the elderly living in the community]. Cad Saude Publica. 2007;23(5):115160. Portuguese.

9. Silvestre JA, da Costa Neto MM. [Approach to the elderly in family health programs]. Cad Saude Publica. 2003;19(3):839-47. Portuguese.

10. Bonardi G, Souza VB, Moraes JF. Incapacidade funcional e idosos: um desafio para os profissionais de saúde. Sci Med. 2007;17(3):138-44.

11. Alves LC, Quinet Leimann BC, López Vasconcelos ME, Sá Carvalho M, Godoi Vasconcelos AG, Oliveira da Fonseca TC, et al. [The effect of chronic diseases on functional status of the elderly living in the city of Saao Paulo, Brazil]. Cad Saude Publica. 2007;23(8):1924-30. Portuguese.

12. Sociedade Brasileira de Reumatologia. Projeto Diretrizes. Osteoartrite (Artrose): Tratamento, 2003.

13. Ricci NA, Kubota MT, Cordeiro RC. [Agreement between observations on the functional capacity of home care elderly patients]. Rev Saude Publica. 2005;39(4):655-62. Portuguese.

14. Arokoski MH, Haara M, Helminen HJ, Arokoski JP. Physical function in men with and without hip osteoarthritis. Arch Phys Med Rehabil. 2004;85(4):574-81.

15. Giorgi RD. A osteoartrose na prática clínica. Temas de Reumatologia Clínica 2005;6(1):17-30.

16. Morgan CR, Santos FS. Estudo da estimulação elétrica nervosa transcutânea (TENS) nível sensório para efeito de analgesia em pacientes com osteoartrose de joelho. Fisioter Mov. 2011;24(4):637-46.

17. Emery P. Treatment of rheumatoid arthritis. BMJ. 2006;332(7534):152-5.

18. Costa AF, Brasil MA, Papi JA, de Azevedo MN. Depressáo, ansiedade e atividade de doença na artrite reumatóide. Rev Bras Reumatol. 2008;48(1):7-1.

19. Snow MH, Mikuls TR. Rheumatoid arthritis and cardiovascular disease: the role of systemic inflammation and evolving strategies of prevention. Curr Opin Rheumatol. 2005;17(3):234-41.

20. Louzada-Junior P, Souza BD, Toledo RA, Ciconelli RM. Análise descritiva das características demográficas e clínicas de pacientes com artrite reumatóide no estado de São Paulo, Brasil. Rev Bras Reumatol. 2007;47(2):84-90.

21. Ferreira LR, Pestana PR, Oliveira J, Mesquita-Ferrari RA. Efeitos da reabilitação aquática na sintomatologia e qualidade de vida de portadoras de artrite reumatóide. Fisioter Pesqui. 2008;15(2):136-41.

22. Salvarani C, Cantini F, Hunder GG. Polymyalgia rheumatica and giant-cell arteritis Lancet. 2008;372(9634):234-45.

23. Neves, CM, Teixeira H, Granja M. Polimialgia reumática: as dores que se multiplicam. Rev Port Med Geral Fam. 2012;28(3):196-200.

24. Cunha LL, Mayrink WC. Influência da dor crônica na qualidade de vida em idosos. Rev Dor. 2011;12(2):120-4.

25. Navas LR, Lyles KW. Osteoporose. In: Duthie, Katz. Geriatria Prática. $3^{a}$ ed. Rio de Janeiro: Revinter; 2002. 211-20p.

26. Berti G, Schallenberger C, Haas L, Giacomelli T. Hidroterapia aplicada ao tratamento da fibromialgia: avaliaçáo clínica e laboratorial de pacientes atendidos no Centro Universitário Feevale em Novo Hamburgo - RS. Ef Deportes. 2008;13(122).

27. Rennó AC, Driusso P, Ferreira V. Atividade física e osteoporose: uma revisão bibliográfica. Fisioter Mov. 2001;13(2):49-54

28. International Osteoporosis Foundation (OIF). Congresso Mundial de Osteoporose da OIF- o primeiro congresso mundial na regiăo com foco na doença que torna ossos frágeis; Rio de Janeiro, Brasil. 2004;14-18.

29. Szejnfeld VL. Osteoporose. Rev Bras Med. 2004;61(7):417-28.

30. Nevitt MC, Cummings SR, Stone KL, Palermo L, Black DM, Bauer DC, et al. Risk factors for a first-incident radiographic vertebral fracture in women $>$ or $=65$ years of age: the study of osteoporotic fractures. J Bone Miner Res. 2005;20(1):131-40.

31. Navega MT, Oishi J. Comparaçáo da qualidade de vida relacionada à saúde entre mulheres na pós-menopausa praticantes de atividade física com e sem osteoporose. Rev Bras Reumatol. 2007;47(4):258-64.

32. Driusso P, Neves VF, Granito RN, Rennó AC, Oishi J. Redução da dor em mulheres com osteoporose submetidas a um programa de atividade física. Fisioter Pesq $2008 ; 15(3): 254-8$ 